\title{
Understanding Perceptions about the Role of Traditional Practices of Inheritance With Relation To Feud Settlement
}

\author{
Aman Ullah ${ }^{1}$, Hina Ashra \\ University of Swabi, Pakistan
}

Mussawar Shah

The University of Agriculture, Peshawar, Pakistan

\begin{abstract}
Pakistani society depicts a vivid picture of inequality in property ownership with prenatal preference to inheritance for sons over daughters. The customary law under the clutches of patriarchy is only meant for male dominating female in all social spheres. The main purpose of this study is to explore the extents of traditional approaches to feud settlement regarding inheritance as the main reason of dysfunctional legal system in the study area. A sample size of 182 respondents was randomly selected of those respondents who had at least 10 acres of land. Frequency distribution of data was observed to have a comprehensive data layout. Moreover, Chi square $\left(\chi^{2}\right)$ statistics was used to determine the level of association between dependant variable (Feud Settlement) with the independent variables (Customary Practices of Inheritance). Majority (78.0\%) of the respondents believed that Jirga played an important role in transformation of inheritance while curtailing the chances of inheritance feuds through application of traditional practices. Most (89.6\%) of the respondents disclosed that patriarchal system favors male members of the family in respect of transferring of property. At bi-variate level, Jirga played a vital role in the transformation of inheritance in case of conflict and had a significant association ( $\mathrm{p}=0.039$ ) with feud settlement. Moreover, dowry to be considered as a share in inheritance of family had a significant association $(\mathrm{p}=0.005)$ with feud settlement. The study depicted that strong patriarchal system was influencing the inheritance practices in favor of male gender. In addition, Pakhtoon culture, being conservative and prejudice, was found to be the core impediment in the smooth transmission of equal property rights to both the gender. Women's participation in the traditional mechanism of resolving the issue of inheritance and speedy court system could lead to the mitigation of inheritance related feuds at family level.
\end{abstract}

Keywords: Customary, Patriarchal, Inheritance, Family, Feuds, Settlement

\section{Introduction}

The mode of transformation with regard to the movable or irremovable property in a particular heresy, throughout the world, enters the field of inheritance. It is a constant right of man to his legal heirs over property ownership, usually by the ancestral hierarchy in the parameters of the defined law. It justifies the transfer of ownership or otherwise the exclusion of the heirs of the property belongs to a line of decent in both ways. The inheritance system is mainly controlled and regulated by well-defined cultural norms in the shadow of the specific roles of family ties which also dedicate the social differentials between members of various societies in the overview of the relative cultural explanation of inheritance, i.e. transfer material assets with family-related associations with goods and other property belonging to a well-defined material assessment such as jewelery, livestock, cash, etc (Aydin \& Damgaci, 2017; Faltis, 2014). It is a phenomenon responsible for social cohesion within the generations at the level of the family. These inherited links, interpreted by the relation of blood, are an indication of the degree of variation of paternal affection. It is considered a permanent communication base at the micro level, such as a family with birth identification as well as income and other cultural associations (Abbas \& Yigit, 2015; Accurate Reliable dictionary, 2008;

${ }^{1}$ Co-responding Author. Aman@uoswabi.edu.pk 
Awaz foundation, 2010; Derre \& Cheryl; \& Kosman, 1988; Yigit, 2015a,).

Customs law is enshrined in the provision of property, although women are denied just that. However, it is often replaced by the provision of dowry, as revealed by Dasscopoulous (1990), that the civil rights of 1804 in France explored the place of enjoyment of civil liberties and religious freedom. Even then, the husbands had the dominant role over their wives. But England witnessed the inheritance of women's rights by securing their access to property (Ahmet, 2016; Shah, 2016). By contrast, in 1840 women were legally subordinated to their husbands and prevented from controlling their own property. The scenario changed when the French and the women of the United Kingdom received the same rights and powers as men. The same was done in the US and China. It has also promulgated the law of equality regarding the right to female and male inheritance (World Bank, 2010). Andikrah (1990) has examined the distribution of property among the Swazi tribes, who are sinking from the older members to the daughter and minor sons of the family. The denial of the right to women led to the emergence of a phenomenon in which sons who had their parents' only inheritance had a moral duty to look after their sisters until their marriages. Widows with low stature were also the social and economic obligation to their brothers on the condition of allocating certain shares to older widows who have no chance to marry (Citamak \& Yigit, 2012; Nicoletti, 2007) or on the other hand, the legal regulations had complications in the exemption of the widow right Inheritance in a marriage seat, where man rules over land and property(Ahmed,2016;Asimwe, 2006; Derre \& Cheryl, 2006; Kameri-Mbote, 2001; Kanabahita, 2006; Munalula, 1995; Matere-Lieb, 1995; \& Narayan et al, 2000).

Patriarchal practices were one of the major disadvantages for women, such as the denial of access to property for their heritage (Abbas \& Yigit, 2016; Narayan et al., 2000). Some other practices, such as resistance to the division of property, refer to Malaysia, but it is based on a common consensus between the descendants of the deceased (Strange \& Heather 1980). Banks (1976) disclosed the division of property, which often consists of two phases, shortly after the death of the owner, i.e. one is informal, which usually benefits children in the household and spouses, while sons and daughters receive equal rights to the property. The second stage relates to the distribution of official law which is often done under the shadow of Islamic law. Afghan customs with reference to women's heritage are subject to consideration of ethnic and regional background. Willy and Alden (2004) describe in the Faryab region (Afghanistan) the official record for women's heritage among the Tajiks. However, this procedure is lacking among Arabs and Pashtun with a clear denial to women in Uzbekistan as well. On the contrary, land ownership for women is a common practice in Laghman. In Bangladesh, a woman does not claim her share in the father's heritage but uses it as a direct contact with the father's household (World bank, 1990). It has also been noted that most women give their rights to their citizens for security if divorced or widowed. Sudanese women have limited access to land as government directors and to register land for connection services, which are often regarded as male activities with the sole purpose of participation in men and women (See Badri, 1986)

Pakistan becomes a Muslim state and is subjected both by the patriarchal family system and by religious rules that are strictly followed up with the idea of showing certain characteristics necessary for the structural and functional integration of society. Pakistani society vividly displays an image of inequality in ownership with prenatal reference to inheritance for sons, while daughters are deprived of their prenatal property. The ordinary law under the strong platform of patriarchy is only intended to let male dominion over the functional system of social life. In addition, the tribal vet experts across the country have also led to the murder of women while they indicted them as honor killings. Shah, (1997) has an in-depth study of honor killings and has reflected this in the possession of money, property and inheritance. Land is an important determinant of power and is considered a sacred element for the honor of the family (Eglar, 1960). Pakistani society, although religious in its ideology, also denies the good transfer of property to daughters. A nonfunctionality of social dynamics with regard to the distribution of property of the common ancestor among his descendants has led to the development of the very famous concept of TAR Borwali, which means the division of property between paternal relatives under Pakhtun (See Barth,1981).

This study will endeavor to discover the effects of patriarchal system with customary law and traditional practices regarding division of property. Moreover, it will also explore the extend of success of traditional approaches to feud settlement related to inheritance as the main reason of dysfunctional legal system in the study area.

\section{Objectives of the Study}

1. To assertion the opinion of sampled respondents regarding feuds over the inherence

2. To explore socio-cultural factors affecting division of inheritance share 
3. To measure the association between independent variable and depended variable.

4. The suggested policy recommendations on the bases of study findings..

\section{Methodology}

\section{Research Design}

In present study correlation design was used. It is most commonly used design in social sciences especially when the data are based on survey research. In this design collected data are used for developing casual relationship between independent variable and dependent variable and also given a "snapshot" of the data regarding phenomenon in a population at a specific point in time (Suliman et al., 2016).

\section{Sampling}

The present research study was carried out in District Mardan to measure the relationship between patriarchal practices of inheritance with family feud settlement. The main reason for selecting Tehsil Mardan was the availability of large portion of agriculture land with respect to ownership of local community. Only those population was selected whose land was not less than Ten acre (10 acres) and the owners must had at least on sister or brother. A sample size of 181 respondents with the above mentioned characteristics was randomly selected for data collection through the criteria set out by Sekaran (2003) from a Total population of 319 .

\section{Conceptual Framework}

The conceptual frame work was designed with the independent variable (customary and patriarchal practices of inheritance) and dependent variable (family feud settlement).

Table 1:

Conceptual Frame Work

\begin{tabular}{ll}
\hline Independent variable & Dependent variable \\
\hline Customary and Patriarchal Practices of & Family Feud Settlement \\
Inheritance & \\
\hline
\end{tabular}

\section{Tool for Data collection}

An interview schedule on Likert scale was used while keeping into considerations the aforementioned objective of the study.

\section{Analysis of Data}

Collected data was converted on to SPSS 20 version. The data was analyzed in frequency and percentages. Moreover, to find out the association between independent variable (customary and patriarchal practices of inheritance) and dependent variable (family feud settlement), the Chi-Square test statistic was applied at bi-variate level. The formula for this application is as below;

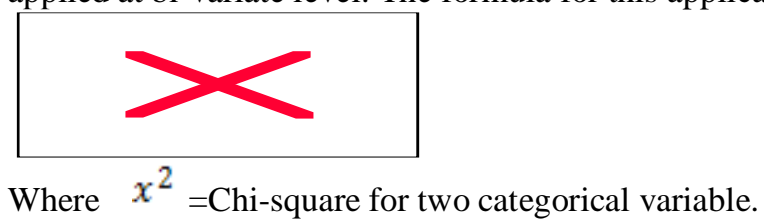

$\sum_{i=1}^{r}=\frac{\text { Total of ith row }}{r+1}$

$\sum_{j=1}^{r}=\quad$ Total of ith Colum

$O_{i j}$ and $e_{i j}=$ represent the observation and expected value shown by Chaudray and Kamali1996)

\section{Result and Discussion}

\section{Customary \& Patriarchal Practices of Inheritance}

Table 2 summarizes the respondent's perception regarding customary \& patriarchal practices of 
Inheritance. The study explored that almost (54.4\%) of the sampled respondents were of the view that Pukhtun custom was one of the major barriers for women to inherit property but a large number of respondents did not support it. It is an outcome of patriarchy, however, women were not denied of their due rights rather bestowed on them as per religious injunctions. Wisal and Inam (2006) have explained Pakhtunwali (a set of codes of pakhtun's life) also in favor of inheriting women practices are going in contrast for the perceived reason of women having no bread earning in the community. Furthermore, in traditional tribal customs in Pakistan, sons tend to enjoy the right of receiving almost all the assets left by their parents, while women generally do not receive or are obliged to surrender their legal share in inheritance. Being daughters, women are often also expected to forego their rights to inheritance in favor of their brothers. Their claim to get their inherited share in property may result in their desertion by their parental side. (Ahmad et al,. 2012). However, most of the respondents $(81.9 \%)$ were of the view that women felt hesitation in demanding inheritance while half of the respondents $(56.6 \%)$ unearthed that women are not married to keep land in family besides a large number $(44.0 \%)$ believed that in some families women were married to Quran to deny her inheritance' rights and keeping the family assets within the family premises. In Pakistan feudal families didn't allow their women to marry in some cases but were supposed to wed to Quran to stop the division of inheritance or to keep family land within family (Awaz Foundation, 2010). A sizeable number (36.3\%) of the respondents in study area disclosed that dowry was considered family's inheritance share in our community while majority had no agreement to this effect. Customary law had a provision of share in land but the people denied such right of women and somewhere in the same communities people substituted it with dowry. The inheritance rights of daughters were significantly limited even when a daughter was only a child. However Swazi women are culturally not entitled for their share in lands (Andikrah, 1990; Dascalpoulos, 1990; and Erez, 2006). The above findings are closely in line with Ahmad (2013) that in pakistan Land is divided as inheritance only among the males on the basis of equality. The eldest brother is generally given an extra share to be used for the upkeep of the family guest house (hujra).

Table2:

Frequency Distribution of Responses about Customary /Patriarchal Practices of Inheritance

\begin{tabular}{llllll}
\hline $\begin{array}{l}\mathrm{S} . \mathrm{N} \\
\mathrm{O}\end{array}$ & Attributes & Agree & disagree & $\begin{array}{l}\text { Don't } \\
\text { know }\end{array}$ & Total \\
\hline 1 & $\begin{array}{l}\text { Jirga played a vital role in the } \\
\text { transformation of inheritance to } \\
\text { heirs/area hose in cases of } \\
\text { dispute }\end{array}$ & $142(78.0)$ & $34(18.7)$ & $6(3.3)$ & $182(100)$ \\
& & & & \\
& & & &
\end{tabular}


2

Inheritance is divide more peacefully through customary practice than legal system

3 Inheritance practices are generally patriarchal or favor male as cultural obligation

4 In patriarchal system male make decision regarding the division of inheritance

5 Patriarchal practice transfers the inheritance to the male member of the family In patriarchal system inheritance given to daughter in the absence of son

7 It is actually the Pakhtoon custom and tradition that help denying women share in family inheritance Pociety women feel hesitation in demanding inheritance share from brothers In traditional set up to keep land and property in the family women are denied from marriage

10 Women in some family are married to Quran to keep the inheritance in the family

11 Dowry is considered share in inheritance in your family

104(57.1)

88(48.4)

99(54.4)

103(56.6)

80(44.0)

66(36.3)
132(72.5)
$132(72.5)$
42(23.1)
$8(4.4)$
182(100)
142(78.0)
29(15.9)
11(6.0)
182(100)

69(37.9)

9(5.0)

182(100)

163(89.6)

9(4.9)

10(5.5)

182(100)

75(41.2)

19(10.4)

182(100)

75(41.2)

8(4.4)

182(100)

149(81.9)

31(17.0)

2(1.1)

182(100)

66(36.3)

13(7.1)

182(100)

70(38.5)

32(17.6)

182(100)

110(60.4)

6(3.3)

182(100)

Note. Values in table present frequency while values in parenthesis represent percentage proportion of respondents.

\section{Family Feuds Settlement}

Feud over the land in both countryside and metropolitan Pakistan are frequent and covering all other immoveable property is one of the major factor of internal conflict as explored by Barth (1959) that land is one of the major root of dispute among intra and inter tribal composition. In Pakhtun society blood kin i.e. Sons, and cousins of the same family have enmity on the family inheritance share (Tribal Analysis Center, 2010). Table-3 disclosed information's regarding the respondent's outlook about family feuds on family inheritance. More than half of the respondents $(61.5 \%)$ had opined that there was no feud in our family over the inheritance and that it has been divide peacefully among legal hairs. Out of $(100 \%),(68.7 \%)$ of the respondents stated that due to non-transformation of inheritance family land remain, which further lad to disturbances of family structure as answered by more than two third of sampled respondents (73.6\%). in addition, nearly all of the respondents stated that the major cause of family disputes among legal hairs was the non transformation of Family inheritance property. Furthermore, more than half of the sample size $(54.9 \%)$ stated that often conflicts are aroused after the distribution of family inheritance share among legal hires. This may reflect the fact the negligence in smooth transformation of property was one of the key cause of quarrel. As explore by Nagata (1976) mostly divisions of property are contributing factor of other disputes. Out of $(100 \%),(96.2 \%)$ reveal that on time allocation of inheritance share was a appropriate way of circumvent inheritance share problems. Similarly, almost all (92.3\%) of the sample size had opined that smooth transformation lead to good relation among blood kin. As Finch and Jennifer (1990) stated that equal distribution of family shares by parents vanishing disputes on family inheritance property . in addition, half of the sample size stated that culture had no way to solve disputes on land while some of the respondents $(50.5 \%)$ deny this statement. Though, nearly everyone in sample size $(90.7 \%)$ 
stated that current laws needed to be changed for provision of remedy. As explored by Business AntiCorruption Portal (2009) that in Pakistan judiciary system was not functions properly and being corrupt only serving the interests of the elite segment of the society only.

Table 3:

Frequency Distribution of Responses towards Family Dispute over the Inheritance

\begin{tabular}{|c|c|c|c|c|c|}
\hline S.no & Attribute & Agree & Disagree & Don't know & Total \\
\hline 1 & There is no feud in the family & $112(61.5 \%)$ & $70(39.5 \%)$ & $0(0.0 \%)$ & $182(100 \%)$ \\
\hline 2 & $\begin{array}{l}\text { Inheritance has been transferred } \\
\text { very peacefully }\end{array}$ & $129(70.9 \%)$ & $47(25.8 \%)$ & $6(3.3 \%)$ & $182(100 \%)$ \\
\hline 3 & $\begin{array}{l}\text { Inheritance is divide unequally in } \\
\text { your family }\end{array}$ & $47(28.8 \%)$ & $129(70.9 \%)$ & $6(3.3 \%)$ & $182(100 \%)$ \\
\hline 4 & $\begin{array}{l}\text { Family lands are always at stable } \\
\text { due to non-practices of } \\
\text { inheritance }\end{array}$ & $125(68.7 \%)$ & $44(24.2 \%)$ & $13(7.1 \%)$ & $182(100 \%)$ \\
\hline 5 & $\begin{array}{l}\text { Denial to inheritance, instable } \\
\text { family structure co-exist together }\end{array}$ & $134(73.6 \%)$ & $35(19.2 \%)$ & $13(7.1 \%)$ & $182(100 \%)$ \\
\hline 6 & $\begin{array}{l}\text { Non transformation of property } \\
\text { right are the main cause of } \\
\text { conflict }\end{array}$ & $169(92.9 \%)$ & $11(6.0 \%)$ & $2(1.1 \%)$ & $182(100 \%)$ \\
\hline 7 & $\begin{array}{l}\text { Strong conflict refaced within the } \\
\text { family after distribution after } \\
\text { inheritance }\end{array}$ & $100(54.9 \%)$ & $74(40.7 \%)$ & $8(4.4 \%)$ & $182(100 \%)$ \\
\hline 8 & $\begin{array}{l}\text { Timely distribution of inheritance } \\
\text { is the suitable way of avoiding } \\
\text { inheritance }\end{array}$ & $175(96.2 \%)$ & $6(3.3 \%)$ & $1(0.5 \%)$ & $182(100 \%)$ \\
\hline 9 & $\begin{array}{l}\text { Smooth transformation of } \\
\text { inheritance brought good relation } \\
\text { among family member }\end{array}$ & $168(92.3 \%)$ & $12(6.6 \%)$ & $2(1.1 \%)$ & $182(100 \%)$ \\
\hline 10 & $\begin{array}{l}\text { Local cultural has no remedy to } \\
\text { settle dispute over land }\end{array}$ & $57(31.3 \%)$ & $92(50.5 \%)$ & $33(18.1 \%)$ & $182(100 \%)$ \\
\hline 11 & $\begin{array}{l}\text { Judiciary laws need to be } \\
\text { amended for just provision of } \\
\text { remedy }\end{array}$ & $165(90.7 \%)$ & $14(7.7 \%)$ & $3(1.6 \%)$ & $182(100 \%)$ \\
\hline
\end{tabular}

Note. Values in table present frequency while values in parenthesis represent percentage proportion of respondents.

\section{Relationship between Customary and Patriarchal Practices of Inheritance and Family Feud Settlement}

Feud over the inheritance land is considered as one of a common phenomenon in Pakistani society but due to political influence and time consuming as a legal trial, are hardly resolved. These conflicts are rather resolved through customary law such as in Pakhtun society, land disputes are handled by the traditional Jirga system. While in the provinces such as Punjab and Sindh, local leaders and Panchayat members often hear and resolve land disputes (Ali and Javid, 2001). Table-4 provides information on the relationship between customary practices of inheritance and family feud settlement. A significant association between jirga plays a vital role in transformation of inheritance in case of conflict was detected with interacting variable $(=0.039)$ i.e. Family Feud Settlement. However, Pakhtun customs and traditions always deny women's share in family inheritance as indicated by a significant $(=0.022)$ relation with Family Feud Settlement. Similarly, in pakhtoon society women feel hesitation in demanding Inheritance' share from brothers $(=0.011)$ was also found significant with Family Feud Settlement. It is eminent from these findings that law pertaining to inheritance over male and female as co-sharing entities, however, pakhtoon culture restricts them in availing this right. World Bank (2011) has also spelled out in consistence to such findings that local justice tends to be more accessible to the poor, relatively quick and cheap for example in Kenya where traditional institutions are widely held to be more reliable in resolving conflicts than the state. At the same time study showed a male dominance and denying of women inheritance right that had 
significant association with family feud settlement. Likewise, Patriarchal practice transferred the inheritance to the male member of the family, was found significant $(=0.033)$ to family feud settlement. This clearly indicated the fact that male's dominance was prevalent in the study area. In Punjab usually conflicts over the inheritance amongst male heirs are easily resolved (Holden \& Azam, 2013). Similarly, the study also provided information about the drawbacks in customary practices such as in traditional set up women were denied from marriage to keep land and property in the family as was found significant $(=0.007)$ with family feud settlement in relationship. Moreover, dowry was considered a share in inheritance of family and was significantly associated $(=0.005)$ with family feud settlement. Thus, a number of petty means have been explored and designed by the male in the study area for restricting women to have access to property rights; which was an obvious outcome of patriarchy.

Human right (2003) and Ersoy and Ugur (2015) explained in its report that patriarchal practices over the inheritance where man controls and inherits family property while women have lesser opportunity. Unlike above, the study explored a non-significant association between family feud settlement with Inheritance is divided more peacefully through customary practices than legal system $(=0.601)$. It is almost in line with the earlier findings where women were found incapable of asking for their rights due to the highly restricted culture (Damgaci \& Aydin, 2013). Business Anti-Corruption Portal (2009) observed that Often Panchayat cannot settle down the disputes or give more importance to wealthy etc so that the case were taken to a formal court. Likewise, inheritance practices are generally patriarchal or favor male as cultural obligation $(=0.283)$. This indicated for a subtle and transparent legal system, however, women had little liberty to gain an access due to her secondary position. An addition, in patriarchal system male made decision regarding the division of inheritance $\quad(=0.782)$ and was found non-significant with family feud settlement, along within patriarchal system inheritance was given to daughter in the absence of son $(=0.060)$. These finding were in line to Desmarais and Lerner (1994) who disclosed that conflict over the inheritance usually occurred when the family members denied or did unfair with legal heirs at the time of distribution of family inheritance. Moreover, women in some families were married to Quran to keep the inheritance in the family and was found non-significant $(=0.590)$ to Family Feud Settlement. These results indicated toward the existence of these practices as myth and had no relation to legal obligation as these were devoid of such activities (Ersoy \& Deniz, 2016). Awaz Foundation (2010) explained the chain of relationship among close siblings that in Pakistan mostly women keep strong relation with their brother and that's why they relinquish their inheritance to avoid family feuds over the inheritance property. Because inheritance conflict can cause separation in families, creating cut-offs and other destructive family dynamics (Lustbader, 1996; Stum, , 2000; and Titus et al., 1979).

Table 4:

Relationship between Customary and Patriarchal Practices of Inheritance and Feud Settlement

S.N O Attributes Response $\quad$ Feud Settlement $\quad$ Total Chi-square

Agree Disagree

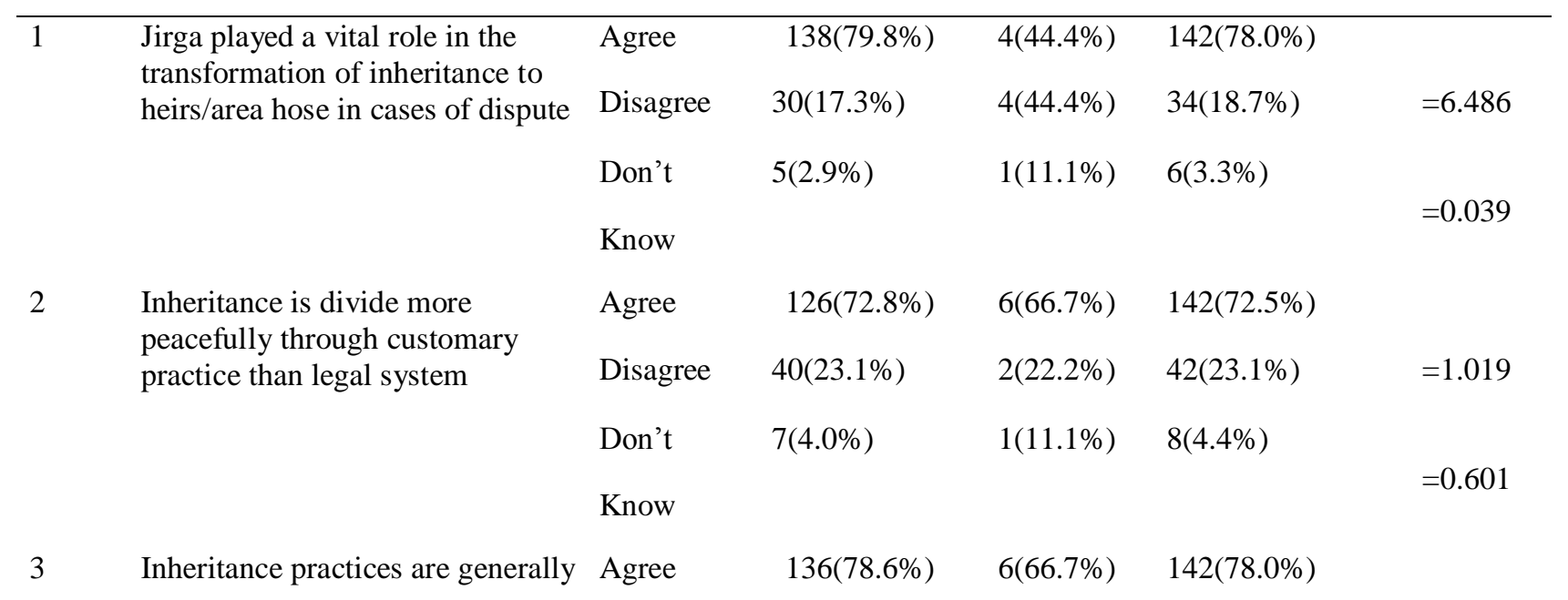


Aman Ullah, Mussawar Shah and Hina Ashraf

patriarchal or favor male as
cultural obligation

\begin{tabular}{|c|c|c|c|c|}
\hline Disagree & $26(15.0 \%)$ & $3(33.3 \%)$ & $29(15.9 \%)$ & $=2.528$ \\
\hline Don't & $11(6.4 \%)$ & $0(0.0 \%)$ & $11(6.0 \%)$ & \\
\hline \multicolumn{5}{|l|}{ Know } \\
\hline Agree & $99(57.2 \%)$ & $5(55.6 \%)$ & $104(57.1 \%)$ & \\
\hline Disagree & $66(38.2 \%)$ & $3(33.3 \%)$ & $69(37.9 \%)$ & $=1.080$ \\
\hline Don’t & $7(4.0 \%)$ & $1(11.4 \%)$ & $8(4.4 \%)$ & \\
\hline \multicolumn{5}{|l|}{ Know } \\
\hline Agree & $157(90.8 \%)$ & $6(66.7 \%)$ & $163(89.6 \%)$ & \\
\hline Disagree & $7(4.0 \%)$ & $2(22.2 \%)$ & $9(4.9 \%)$ & $=6.813$ \\
\hline Don't & $9(5.2 \%)$ & $1(11.1 \%)$ & $10(5.5 \%)$ & \\
\hline \multicolumn{5}{|l|}{ Know } \\
\hline Agree & $84(48.6 \%)$ & $4(44.4 \%)$ & $88(48.4 \%)$ & \\
\hline Disagree & $73(42.2 \%)$ & $2(22.2 \%)$ & $75(41.2 \%)$ & $=5.612$ \\
\hline Don’t & $16(9.2 \%)$ & $3(33.3 \%)$ & $19(10.4 \%)$ & \\
\hline
\end{tabular}

Know

In patriarchal system inheritance given to daughter in the absence of son

In patriarchal system male make
decision regarding the division of inheritance

Patriarchal practice transfers the inheritance to the male member of the family

It is actually the Pakhtun custom and tradition that help denying women share in family inheritance

Agree

Disagree

$94(54.3 \%)$

$5(55.6 \%)$

$99(54.4 \%)$

$73(42.2 \%)$

Don't

$6(3.5 \%)$

Know

8

In Pakhtun society women feel hesitation in demanding inheritance share from brothers

Agree

Disagree

Don't

Know

9

In traditional set up to keep land and property in the family women are denied from marriage

10

Women in some family are married to Quran to keep the inheritance in the family
Agree

Disagree

Don't

Know

Agree

75(43.4\%)

$5(55.6 \%)$

$80(44.0 \%)$

Disagree

$68(39.3 \%)$

$2(22.2 \%)$

$70(38.5 \%)$

$=1.055$

$\begin{array}{llll}\text { Don't } \quad 30(17.3 \%) & 2(22.2 \%) & 32(17.6 \%)\end{array}$ 
Know

11 Dowry is considered share in

Agree

$63(36.4 \%)$

$3(33.3 \%)$

$66(36.3 \%)$ inheritance in your family

$\begin{array}{llll}\text { Disagree } & 106(61.3 \%) & 4(44.4 \%) & 110(60.4 \%) \\ \text { Don't } & 4(2.3 \%) & 2(22.2 \%) & 6(3.3 \%)\end{array}$

Know

\section{Conclusions and Recommendations}

This study concluded that Jirga, an informal institution for dispute settlement in Pakhtun culture, plays vital role in the dispute settlement related to inheritance matters. It may reflect the truth that legal (Judicial) system of the country is not functioning properly. Patriarchy was found having a leading role in practices pertaining to inheritance. This study further explored the incapability of male regarding divisions of property resulting in feuds among the real heirs. This ultimately leads to the nonproduction of land. Pakhtun culture was found a major obstacle in transformation of these rights due to strong traditional control which denies women of their due right. Furthermore, the arrangement of dowry by the bride's family was considered a share of heirs within the property from their ancestor. Women participation in traditional dispute settlement mechanism, revising the patriarchal system in terms of gender based consideration were some of the recommendations extended in light of this study

\section{Limitations of the Study}

The study focuses on the inheritance matters majorly but it limits a focus on the cultural aspects of Pakistani society. It lacks a deep insight into the dysfunctional characteristics of the judicial system in the country. In connection to the above, it lacks a peer look on the inefficient role of the family and educational setup that finally results in denial of female share in the property.

\section{Direction for Future Research}

Future research must be conducted on the female liberty regarding their economic empowerment. Women economic dependency must be sorted out in the legal and social spheres. Patriarchy patterns must be revised giving due importance to female participation in property matters Research on traditional clutches hampering women involvement in social welfare activities must be made functional. Patriarchy patterns must be revised giving due importance to female participation in property matters. Research based education that focuses on inheritance matters and property rights must be given utmost importance at secondary levels of education.

\section{Reference}

Abbas, T. \& Yigit, I. (2016). Perspectives on Ethno-National Conflict among Kurdish Families with Members in the PKK. Terrorism and Political Violence, 28(2), 297-315.

Abbas, T. \& Yigit, I. (2015). Scenes from Gezi Park: Localisation, Nationalism, and Globalization in Turkey. City, Analysis of Urban Trends, Culture, Theory, Policy, Action 19(1), 61-76.

Adinkrah, K.O. (1990). Folk law is the Culprit: Women's non-rights in Swaziland. Journal Legal Plural \& Unofficial Law, 4(3), 130-131.

Ahmad, M. L. (2013). Ethnicity and Cultural Assimilation among Pakhtoons of District Anantnag in Jammu and Kashmir (Unpublished doctoral thesis). India: The University of Jammu.

Ahmed, M. (2016). Ethnicity, Identity and Group Vitality: A Study of Burushos of Srinagar. Journal of Ethnic and Cultural Studies, 3(1), 1-10.

Ahmad, E., Anbereen, B, \& Tahir, M. (2012). Attitudes towards Women's Rights to Inheritance in District Lakki Marwat, Pakistan, The Pakistan Development Review 51(3), 197-217.

Ahmed, M. (2016). Ethnicity, Identity and Group Vitality: A Study of Burushos of Srinagar, Journal of Ethnic and Cultural Studies, 3(1), 1-10.

Ali, S. S., \& Javid, R. (2001). Indigenous peoples and ethnic minorities of Pakistan: constitutional and legal perspectives. Denmark: Nordic Institute of Asian Studies monograph series. 
Asiimwe, J. (2005). One Step Forward, Two Steps Back: The Women's Movement and Law Reform in Uganda from 1985-2000. In J. Bond, (ed.) voices of African Women: Women's Rights in Ghana, Uganda, and Tanzania. Durham: Carolina Academic Press.

Awaz Foundation. (2010). Denial of women's right of inheritance enhancing their vulnerability to domestic \& societal violence: Research study on customs and practices prevailing in south Punjab regarding women's right of inheritance. Multan-Pakistan: Awaz Foundation Pakistan, Centre for Development Services.

Aydin, H. \& Koc-Damgaci, F. (2017). From Empire to Republic: Citizenship, Pluralism, and Diversity in Turkey. In James, A. Banks (Eds), Global Migration, Structural Inclusion, and Education across Nations [pp. 351-377]. Washington, DC: American Educational Research Association (AERA) Press.

Barth, F. (1981). Features of person and society in Swat: Collected essays on Pathans. London: Routledge \& Kegan Paul.

Badri, B. (1986). Women land ownership and development, the case of Sudan, The Afhad Journal: Women and Change, 3(2), 89-92.

Banks, J.D. (1976). Islam and inheritance in Malaya: Culture, conflict or Islamic revolution. American Ethnologist, 3(4), 573-586.

Business Anti-Corruption Portal. (2009). Pakistan Country Profile: Land Administration pakistan/corruption-level s/l and-administration. Retrieved from www .busi ness-anti corruption.com/country-profi les/southasia/.

Barth, F. (1959). Political Leadership among Swat Pathans. London: Athlone.

Chaudhry, S, M. (2003). Introduction to Statistical Theory Part II. Lahore: Ilmi Kitab Khana.

Citamak, Y. \& Yigit, I. (2012). From Student's Table to Teacher's Desk. International Journal of New Trends in Arts, Sports \& Science Education 1(2), 1-7.

Damgaci, F. \& Aydin, H. (2013). Perceptions of Higher Education Faculty Members on Multicultural Education in Turkey. Dicle Üniversitesi Ziya Gökalp Eğitim Fakültesi Dergisi, 21(2), 314-331.

Faltis, C. (2014). Toward a Race Radical Vision of Bilingual Education for Kurdish Users in Turkey: A Commentary. Journal of Ethnic and Cultural Studies, 1(1), 1-5.

Holden, L., \& Azam, C.(2013). Daughters' inheritance, legal pluralism, man governance in Pakistan, The Journal of Legal Pluralism and Unofficial Law, 45(1), 104-123.

Dascalopoulos, C., S. (1990). The notion of female property: A comparative study of property. The Journal of Legal Pluralism and Unofficial Law, 2(4), 330-352.

Deere, C.D. \& Cheryl, D. (2006). The Gender Asset Gap: What Do We Know and Why Does it Matter, Feminist Economics 12(1-2), 1-50.

Desmarais, S., \& Lerner, M. J. (1994). Entitlements in close relationships: A justice motive analysis. In M. J. Lerner \& G. Mikula (Eds.), Entitlement and the affectional bond: Justice in close relationships (43-63). New York: Plenum.

Eglar, Z. (1960). A Punjabi Village in Pakistan. New York and London: Columbia University Press.

Ersoy, E., \& Ugur, H. (2015). The Relationship between Students' Self-esteem and Parental Attitudes in Turkish Society. The Anthropologist, 21(1-2), 112-119.

Ersoy, E., \& Deniz, M. E. (2016). Psychometric Properties of the Gifted Students' Coping with Anger and Decision Making Skills Scale. Journal of Education and Practice, 7(15), 121-128.

Ezer, T. (2006). Inheritance Law in Tanzania: The Impoverishment of Widows and Daughters. The Georgetown Journal of Gender and the Law, 7, 601-652.

Finch, J. \& Jennifer, M. (1990). Filial Obligations and Kin Support for Elderly People. Aging \& Society, 10(2), 151-175.

Human Rights Watch. (2003). Double standards: women's property rights violations in Kenya. Retrieved from http://www.hrw.org.

Kameri-Mbote, P. (2001). Gender Dimension of Law, Colonialism and Inheritance in East Africa: Kenyan Women's Experience. Geneva: International Environmental Law Research Centre.

Kanabahita, D. (2006). Report on intestate Succession, Law and Advocacy for Women in Uganda. Retrieved from https://www.law.georgetown.edu/rossrights/docs/cases/lawa.html

Lustbader, W. (1996). Conflict, emotion, and power surrounding legacy, Generations, 20, 54-57.

Matere-Lieb. (1995). Basotho Women's role in Urban Housing: The Case of Maseru.In Gruphel, Phase One, Gender Research on Urbanization, Planning, Housing and Everyday Life. Harare: Zimbabwe Women's Resource Centre \& Network.

Munalula, M. (1995). Choice of Law: Theoretical Perspectives on Urbanization and Women's Rights to 
Property in Gruphel Phase On”, Gender Research on Urbanization, Planning, Housing and Everyday Life. Harare: Zimbabwe Women's Resource Centre and Network.

Nicoletti, E. (2007). Women Right's of inheritance and labor. Social Action, 5, 250-287.

Narayan, D., Patel, R., Schaf ft ,K., Rademacher, A., \& Koch-Schulte. (2000). Voices of the Poor: Can anyone hear us? London: Oxford University Press.

Nagata, J, A. (1976). Kinship and Social Mobility among the Malays. Man 11(3), 400-409.

Okumu-Wengi, J. (2001). Women and the law of inheritance. In Tuhaise, P; Matovu, V; Madrama, C; Mbaaga, F; Mugisha, J; and Okumu-Wengi, J, Women and law in East Africa. Kampala: Law Development Centre.

Saeed, R, R. (2004). Women Status in Pakistan under Customs and Values \& the Controversial Hudood Ordinance 1979. Retrieved from econwpa.repec.org/eps/le/papers/0501/0501003.pdf.

Suliman, M., Mussawar, S., Asad, U., \& Humera, J. (2016). Ethnicity Based Social Exclusion of Nomads in Khyber District Malakand, Pakhtunkhwa-Pakistan, and Journal of Ethnic and Cultural Studies, 3(1), 11-19.

Stum, M,S. (1999). I just want to be fair': Interpersonal justice in intergenerational transfers of non-titled property, Family Relations, 48, 159-166.

Shah, M. (2016). Ethnicity Based Social Exclusion of Nomads in Khyber District Malakand, Pakhtunkhwa-Pakistan. Journal of Ethnic and Cultural Studies, 3(1), 11-19.

Shah, N. (1997). Role of community in honor killings in Sindh. In H. Neelum, M. Samiya, and S.Rubina (eds), Engendering the nation-state [12-25]. Pakistan: Simorgh publication.

The World Bank. (1990). Bangladesh: strategies for enhancing the role of women in Economic development. Washington, DC: The World Bank Press.

The World Bank Group. (2010). Women business and the law 2010 The International Bank for Reconstruction and Development. Washington, DC: The World Bank.

The World Bank. (1990). Bangladesh: strategies for enhancing the role of women in Economic development" A World Bank Country Study, Washington, DC: The World Bank Press.

Titus, S, L., Rosenblatt, P, C., \& Anderson, R, M. (1979). Family conflict over inheritance of property. The Family Coordinator, 28(3), 337-346.

Tribal Analysis Center. (2009). Pashtun tribal dynamics. Retrieved from, http://www.tribalanalysiscenter.com/PDF-TAC/Pashtun\%20Tribal\%20Dynamics.pdf

Yigit, I. (2015). Survival Tactics of Waste Paper Pickers in Istanbul. Journal of Ethnic and Cultural Studies, 2(1), 1-14.

Wily, L., A. (2004). Land Relations in Faryab Province. Findings from a field study in 11 villages, Case Studies Series. Kabul: Afghan Research and Evaluation Unit (AREU).

Wisal, K., \& Inam, M. (2006). Gender based socio-cultural constraints in inheritance in Pukhtun society(master thesis). Pakistan: University of Peshawar. 